\title{
Influence of Superimposed Capitalism on Traditional Natural Resource Utilization Systems
}

\author{
Kumara HIGC, Wawwage S and Kodikara GRL \\ Department of Geography, University of Ruhuna, Matara, Sri Lanka
}

\begin{abstract}
Most of the developing countries got capitalism superimposed during the colonial and post-colonial periods through processes of imperialism, globalization, liberalism and neo-liberalism. It was the main reason for the change in rural socio-economic settings. However, 'lack of analytical knowledge regarding those changes' could be identified as a 'knowledge gap'. Considering that, Niyandagala forest reserve, which is located in the Mihidupura GN division in Lunugamvehera DS division was selected as the research area to identify and analyse changes in traditional forest utilization systems under the influence of superimposed capitalism. A qualitative-inductive research methodology has principally guided this research and a total of 38 participants have informed this research including 26 interviews (18 individuals, and 06 different focus-groups). A critical discourse analysis (CDA) method is used to examine both primary qualitative data collected through participant and direct observation, interviews and secondary data. The community residing at the peripheries of the Niyandagala forest reserve consists of isolated and marginalized local villagers who still practice traditional feudal customs. After the end of the1980s, capitalism was superimposed on the site through free trade economic policies of the country which based on contemporary global neo-liberalism ideologies. As one of the characteristics of the process of capitalism being superimposed on local culture, the traditional feudal values of local communities in the site got mixed up with capitalist values creating a 'feudal-capitalist' socioeconomic structure. It was the main reason for changes occurred in local traditional forest utilization systems which shifted from 'feudal value based collectivist' to 'profit oriented individualist' systems. That led into two main changes; first, increasing economic competition and forest degradation; second, rising numbers of villager migration from the site to outside looking for capitalist fantasies and resultant socio-economic disorientation. The main research conclusion is that superimposed capitalism can bring about social anomie. This kind of social change can be harmful to ecosystem as well as socio-economic structure.
\end{abstract}

KEYWORDS: Superimposed Capitalism, Traditional Forest Utilization, Feudal-Capitalism; Kadawara tank, Niyandagala Forest Reserve

Corresponding author: H. I. G. C. Kumara, email: chamindakumara03@yahoo.com 


\section{INTRODUCTION}

Capitalism can simply be defined as a profit oriented economic system, which promotes a private free trade economic market rather than a state cooperative economy (Schumpeter, 2013; Hawken, Lovins, \& Lovins, 2013). Most of the developing countries that were depending on their own traditional economic systems, got capitalism superimposed during the colonial and post-colonial periods through processes of imperialism, globalization, liberalism and neoliberalism (Dirlik, 2002; Banerjee \& Linstead, 2001; Kumara, 2016). It was the main reason for the changes occurred in local traditional socio-cultural structures, which shifted from collectivism towards money centred 'individualism' (Tiessen, 1997; Triandis, Chen \& Chan, 1998). This situation is common to Sri Lanka that is a southern peripheral country in the global geo-political and economic context (Kumara, 2016).

After 1977, the Sri Lankan government wanted to obtain economic development through state capitalism, which was based on neo- liberalism ideologies and free trade economic policies (Dunham \& Jayasuriya, 2000; Stokke, 1997; Moore, 1990). Gradually, 'superimposed capitalism' pierced into Sri Lankan village culture and mixed up with local feudalist systems. As a result, Sri Lankan social structure is gradually moving towards a 'capitalist feudal' society, which steadily brings changes in traditional social beliefs, norms, practices and social relationships (Kumara, 2016). This change has created an individualist culture in the village, because 'capitalism' and 'individualism' are strongly interrelated processes. Individualism as an ideology arose with the beginnings of capitalism (Turner, 1988). The idea that each of us is unique and should be free to do as one wants corresponded with a society of market relations, in which people are connected with one another only through buying and selling (Kumara, 2016).
The Kadawara Wewa site in the Niyandagala forest reserve located in the Mihidupura GN division in the Lunugamvehera DS division (close to the Lunugamwehera National Park) is a sensitive dry zone forest area (Weerasinghe, Jayasinghe, \& Abeysinghe, 2002). It is identified as habitats of many rare species including a large number of wild elephants (Fernando et al., 2011). The peripheral community has used this forest area for animal husbandry, especially for cattle farming, and Chena cultivation over many years using traditional knowledge and practices (Kobbekaduwa, 1998). This traditional economic system can be identified as a context based federal economic system, which promoted collectivist and collaborative activities in the particular social groups.

The peripheral community of the Niyandagala forest reserve which consisted of isolated and marginalized local villagers practicing local traditional feudal values, was untouched by superimposed capitalism until the end the 1980s. Towards the end of the1980s, capitalism was superimposed in this community through free trade economic policies of the country based on contemporary global neo-liberalism ideologies (Dunham \& Kelegama, 1994). As one of the characteristics of the process of capitalism being superimposed on the local culture, the traditional feudal values of local communities in the site got mixed up with capitalist values creating a new set of socio-economic values (Kumara, 2016). For example, in spite of all the modern development achievements of the local communities through capitalism, issues of gender and caste based on traditional feudal values are still in practice (Gunasinghe, 1990). Further, increase in human population, poverty and forest degradation are major issues which are linked with superimposed capitalist ideologies (Kumara, 2016). One of the major trends observed in this forest is its rapid degradation owing to overutilization of forest resources by peripheral community and weaknesses in the state forest management policy (Parrotta, Turnbull \& Jones, 1997). This 
situation is common in peripheral areas of many forest reservations of the country (Kumara, 2014). Therefore, the government must focus more on achieving community development and forest conservation, if it wants to address country's sustainable development targets. As well, understanding and analyzing the role of capitalism and super-imposed capitalism at the particular grassroots context is important for the successful implementation of any community development and forest management programme. Considering all these, the research focuses on identifying traditional forest utilization systems of the peripheral villages of the Kadawara wewa, Niyandagala forest reserve and analyzing the changes occurred in traditional forest utilization systems due to the influence of superimposed capitalism in the particular area.

\section{BACKGROUND}

Global development discourses and theories are mainly based on 'capitalist' and 'socialist' ideologies, which have influenced policymaking and eco management planning in Sri Lanka (De Silva, 2012; Kumara, 2016).

\section{1 'Classical Traditional Approach’}

Capitalist development approaches are two kinds of such as 'classical traditional approach' and 'neoclassical approach'. The classical traditional development approach is the root of modern development processes and 'The Wealth of Nations' (Smith, 2015 -1776) is considered the foundation of 'classical economic development discourse'. It was written when 'capitalism' was emerging from 'feudalism' as a result of the industrial revolution. This approach contributed to the growth of the earliest capitalist economy in the world, however, at the same time, it established euro-centred idealism and that was the weakness of applying this approach on the Sri Lankan context (Desai, 2002; Politonomist, 2009; Potter, 2002).

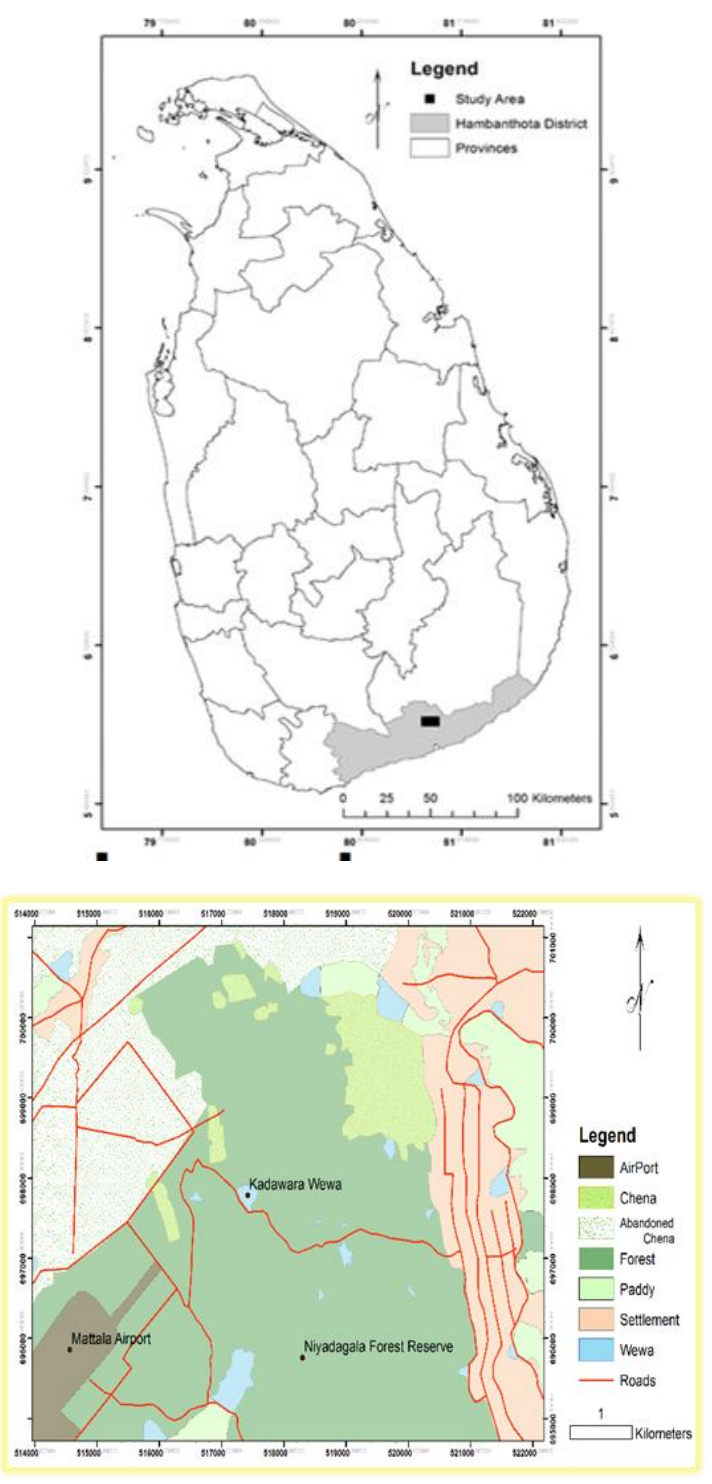

Figure 1. Research site

\subsection{Neo-Classical Development}

At the end of the World War II, ideologies of neoclassical development became more popular as a method of capitalism discourse and an economic reconstruction tool. According to the neoclassical economic philosophy, economic activities may focus on the determination of prices, output, and income according to 'supply' and 'demand' in the market (Davis, 2006; Thomas, 2012). However, according to Marxist theorists this flow creates world development 
processes that result in underprivileged poor states; like Sri Lanka and enhance the wealth of rich states (Costantinos, 1998; Sekhri, 2009).

\subsection{Marxism \& 'Radical Dependency Theory'}

As an antithesis to 'classical and neo-classical development theories and discourses', Marxist and neo Marxist thinkers such as André Gunder Frank, Paul Baran and Paul Sweezy, Samir Amin, Theotônio dos Santos, Arghiri Emmanuel, and Aníbal Quijano developed 'radical dependency theory' (Desai \& Potter, 2002; Fewel, 1981; Vernengo, 2012). According to this theory, development processes of the third world should focus on indigenous economic and social development as well as resource usage patterns of local communities and their interests (Ferraro, 2008; Sekhri, 2009). Radical dependency theory was the most popular development theory until the 1970s and it in/directly influenced to determine Sri Lankan development polices too, yet at the beginning of the 1980s, it faced the difficulty of explaining its own ideologies: growing economic development of some formerly poor countries like 'Asian tigers' challenged its validity as a development discourse (Desai \& Potter, 2002; Friedmann \& Wayne, 2012).

\subsection{Alternative development approaches}

Horrendous pictures of the future world emerged at the dawn of the 1980s seeing prevalent environmental degradation and global warming, which were directly associated to unlimited economic development. Neo Malthusians have theoretically explained 'limits of growth' and they have described the correlation between food production and human population growth, as well as the limitation and degradation of most natural resources (Abramitzky \& Braggion, 2003; Brezis, 2010; Chenowetha \& Feitelsonb, 2004). Consequently, political ideologies have shifted towards nature friendly development discourses. As a result, capitalists use the term 'eco capitalism' and socialists have emphasized 'eco socialism'. Nonetheless, they are still struggling to develop environmentally friendly practical forms of economic development. Hence, researching on this issue has theoretical as well as practical importance (Reed, 2008).

'Post colonialism' is associated with alternative development discourses. Western structures of knowledge and power block the development process in the southern peripheral context (Dirlik, 1994). Thus, post colonialists criticized a development structure based on western 'autonomy' and 'hegemonic power' (Brydon, 2004; d'Hauteserre, 2004; Hall \& Tucker, 2004; Ziai, 2011). Post colonialism supports some alternative development concepts such as the need to conserve cultural and environmental resources, the involvement of local communities in development, the improvement of their living conditions and the availability of sustainable development policy, plan and strategies (Desai \& Potter, 2002; Hall \& Tucker, 2004; Hollinshead, 2004; Ziai, 2011).

Both 'sustainable development' and bottom-up development' approaches have been developed as alternative development tools in the last few decades in many developing countries including Sri Lanka (Altieri \& Masera, 1993; Menge, 1992; Parnwell, 2002). This development approaches are based on community participation and empowerment through their own development and environmental management. 'Eco-managerialism' can be considered an environmental friendly development approach associated to sustainable development discourses. It has deep concerns for ecological management and economic development (Fischer \& Hajer, 1999).

However, regardless of its philosophical rationality, in practice, sustainable development faces many challenges in the Sri Lankan context. Sustainable development approaches account for the need of development combined with environmental conservation, yet, it is not clearly explained how this can be achieved within 
contemporary capitalist and superimposed capitalist development practices (Adams, 2009; Ivanova, 2007; Zizek, 2008).

Conceptually, sustainable development still has significant value (Adams, 2009), however, if Sri Lanka really needs to achieve meaningful sustainable development goals, it should address socio-economic and geopolitical issues in the particular contexts. Forest management and rural poverty reduction in Sri Lanka through community forest management approaches and/or local community participation to gain sustainable outcomes have a contemporarily significant value and to achieve that the Sri Lankan government has used 'sustainable development approaches' as its principal policy. Nevertheless, before implementing any sustainable development approach in the context of developing countries like Sri Lanka, local knowledge and experience as well as socioeconomic structure must clearly be analysed (Adams, 2009; Baker, 1997, 2006; Clark, 2006; Redclift, 1989).

Through the literature review, 'understanding and analyzing the role of capitalism and superimposed capitalism in the rural Sri Lankan context' was identified a 'knowledge gap/vacuum' and the research objectives and questions are formed to bridge that gap.

\section{METHODOLOGY \& METHODS}

\section{1 'Qualitative Research Methodology' and 'Inductive research approach'}

In this research, primary concern was to deal with 'rich and deep' primary data rather than 'numeric' data and much attention been paid to qualitative research methodology. This study targeted to collect philosophies on how 'rich' and 'deep' are intangible factors associated with changes of traditional forest utilization systems due to influence of superimposed capitalism vs sustainable development. Consequently, a 'qualitative inductive research approach' was selected as the dominant methodological approach of this research. There is a profound correlation between qualitative methodology and inductive research. In inductive research, first, data is collected using relevant qualitative data collecting methods and then findings are linked with relevant theories, discourses, and concepts (Bryman, 2012; Thomas, 2012).

\subsection{Data collecting methods}

Secondary data in the research is extracted from the following sources. A number of publications by local and international writers, especially those that include information about development discourses, alternative development, eco development, ecotourism, community forest management, joint forest management, tropical forest management etc. are used in the study. Participant and direct observation, semi-structured interviews and focus group interviews were conducted as qualitative data collection methods for this research. Altogether, 18 semi structured interviews were conducted in this research and each interviewee was provided with a consent form too. Semi-structured interviews are presented by their categorical code. For instance, in 'SSI10 Traditional cattle farmer', 'SSI10' stands for 'semi structured interviewing number 10. Six focused group interviews have also been conducted to the primary data collection process of this research and it is also presented by categorical code as 'FGI4 Villagers' where 'FGI4' indicates 'focused group interviewing number 04'. A total of 38 participants have informed this research including 26 interviews.

\subsection{Sampling Method}

Semi-structured interviews use the 'snowballing' sampling method. Snow-balling is based on the metaphor that when a real snow ball is rolling down the hill, its size gradually increases until it approaches saturation (Baker, 2012; Cohen \& Arieli, 2011). Thus, the researcher must gather enough data using a 
chain referral process until it approaches saturation (Baltar \& Brunet, 2012). This method was useful in this research, since it helped to gather information from diverse respondents.

\subsection{Analysis}

A critical discourse analysis (CDA) method was used to examine both primary qualitative data, which were collected through participant and direct observation, interviews as well as secondary data. The data was analysed using steps such as data understanding, categorizing, coding under themes, connecting with theories and discourses and described narratively (Description/Interpretation/Explanation) (Bloor \&Bloor, 2013; Dey, 2003; May, 1997). Classification of themes from the collected raw data can be recognized as a process (Bryman, 2012). Intensive reading, careful reading and rereading were conducted as a procedure to identify patterns in the data to recognize separate themes (Boyatzis, 1998).

\subsection{Positionality and Reflexivity}

The notion of 'positionality and reflexivity' is normally connected with qualitative research methodology (Guillemin \& Gillam, 2004; Walker et al., 2013). Every human being lives in a highly connected socio-cultural and political network. The nature of that network is different from place to place, culture to culture and time to time. That means every human being enjoys a special socio-cultural, economic and political 'position'. Whatever they do, talk, write, create etc., that 'position' is naturally displayed in their work. The social researcher is also a human being who has a separate 'position' that depends on his/her own socio-cultural values, beliefs, feelings and thoughts (Robert Wood Jonson Foundation, 2012). Many scholars have then argued that 'position' is exposed in many parts of a social research process (Walker et al., 2013). Since this research uses qualitative methodology, researcher was concerned about researcher's 'positionality' through reflexivity.

\section{RESULT \& DISCUSSION}

\subsection{Traditional forest utilization patterns}

The community residing at the periphery of the Niyandagala forest reserve has used Kadawara tank and surrounding areas for multiple needs such as cattle farming, Chena cultivation, poaching and gathering forest material for survival needs. To observe the reality of this situation, we focused on case studies of three main characters and their families in this research.

First case study: ' $A$ ' is a traditional cattle farmer and has used the forest area and Kadawara tank for his profession. According to him,

I am a member of a traditional cattle farming family. Both my father and grandfather had also utilized this forest area for cattle farming. So, traditionally people called us 'Gambara' [people who own a large number of buffalos]. I have more than 200 cattle and from 1965 I have been using this area for cattle grazing. Kadawara tank is a useful water source not only for my animals, but also for all the wild animals in the reserve. I have built a cattle pond very close to the tank. Since more than 300 wild elephants surround the tank looking for water, I have built three tree houses close to my cattle pound thinking about my safety [SSI01- A: traditional cattle farmer, male, 65 years old, 2016.10.14 (This statement was cross checked and was proved by SSI14, 03, 04, 10, 11,12, \& FGI 01, 04)].

This 'A' informant has two residencies; usually his family members, especially women at home, his wife and two daughters, live in a permanent house in the village while he and his helpers spend days and nights in their tree houses to take care of herds of cattle. As he stated, he uses Kadawara tank for fishing and gain extra income every week by selling the fish harvest. According to him; 
This is a state tank, yet I always try to maintain it as it adds to my income. My cattle cannot live without water, especially during the dry season. I have put different edible fish species into this tank and once a week I get more than $50 \mathrm{~kg}$ of harvest by fishing with a net (SSI01A).

Forest utilization patterns of 'A' represent methods of an 'Asian feudal system' which is based on 'collectivism' (Chayanov, 1966; Kumara, 2016). As he explained;

I have about ten people here with me to help my work, but they are not my workers. I do not pay them for their work or I do not keep money with me, instead, my wife take all the income I gained from farming. Most of these helpers around me are my relations and we collectively contribute to our work. For example, every morning and evening my sons and me together milk cows in the herd and take it to my house in the village. Then we take the herds of cattle to the forest for grazing. My wife and daughters boil milk and make curd and send curd to the market but sometimes people come to my house to buy curd. When my helpers or I want money, we get it from my wife. Some of my animals belonged to my father earlier. Since he is no more with us, $I$ own them now. Even if my mother is still alive she does not involve in these activities. Instead, I monthly give her the share of income I gain from those cattle. I have given some of my animals to my sons as well, especially when they have got married, yet still they give me my share of the income. Every week we earn money by fishing in Kadawara wewa. I do not pay people who come to help me with fishing, but I usually buy what they need, for instant clothes and dry food in a latter day with the money we collectively earned (SSI01A).

This kind of social system is built on traditional feudal power relations, values, knowledge, relationships and interests (Kumara, 2016) as well as it has links to the 'social hegemony' and 'cultural idealist superstructure' in the particular context. People in this type of society work as a group and their social relationships create a strong social network (Forgacs, Nowell-Smith, \& Boelhower, 2012). According to Antonio Gramsci (2011), cultural hegemony is based on the cultural norms of a society.

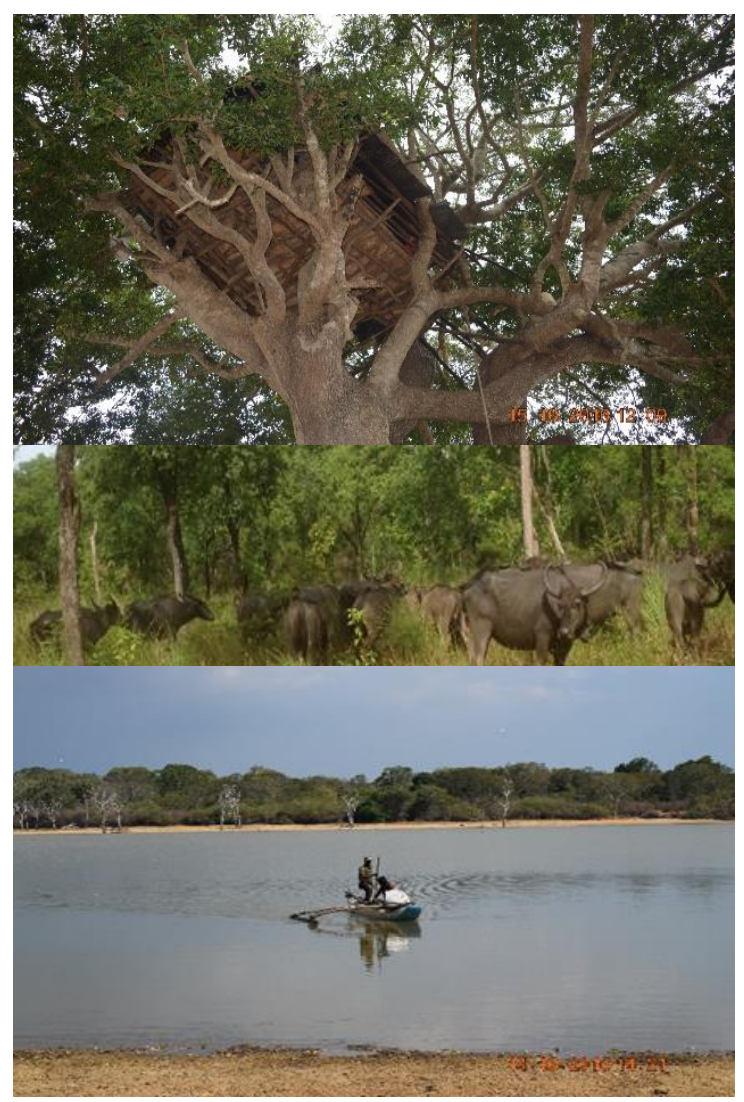

Figure 2. One of the tree houses belongs to A, his cattle grazing free in the forest area \& Kadawara tank

\subsection{Superimposed capitalism \& changes in forest utilization patterns}

Socio-economic situation of the research site has started to change gradually from a traditional feudal system to a superimposed capitalist system by 1980s as a result of changes occurred in state political-economic policy (section 1: introduction) (Dunham \& Jayasuriya, 2000; Stokke, 1997; Moore, 1990). Changes occurred in state political-economic policy 
brought capitalism which is nurtured by 'neoliberalism' and 'individualism' ideologies into the site and it was superimposed on the rural feudal village structure (Turner, 1988). Gradually, 'superimposed capitalism' pierced into village culture mixing with the fundamentals of traditional feudalism. This led to develop 'feudal- capitalist' socio-economic system which is totally different from western capitalism or Asian traditional feudalism (Kumara, 2016; Gunasinghe, 1990).

According to the findings of this research, two main changes in forest utilization can be identified.

01. Traditional forest utilization practices have been moderated and used to increase profit.

02. A considerable number of young villagers in the site has forgotten traditional ways of living and has migrated to outside world looking for better lifestyles following their capitalist dreams.

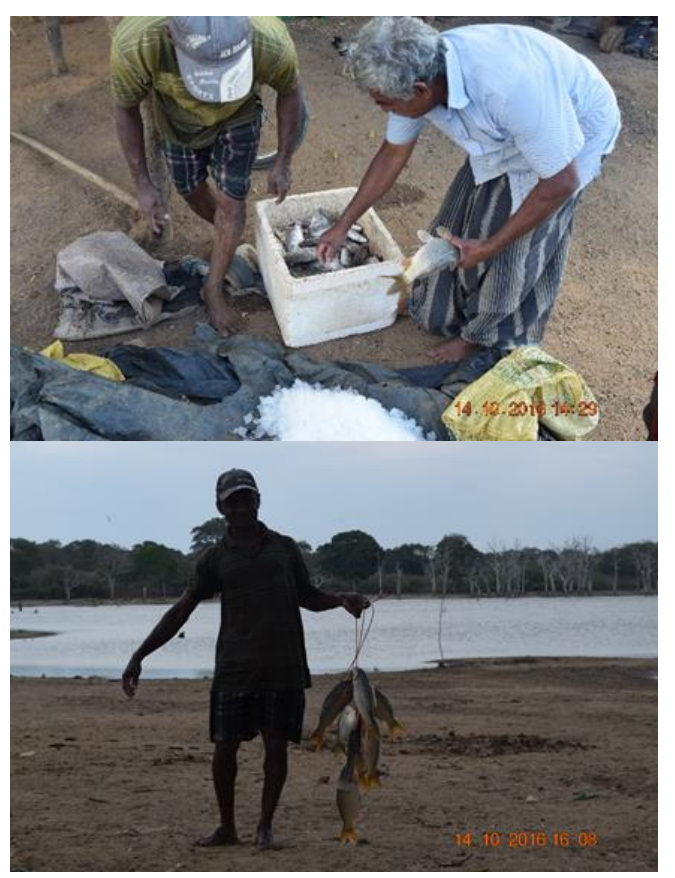

Figure 3. A \& his helpers collect and prepare their weekly fish harvest to the market.
Second case study: A2 is the third son of A. He is not happy with traditional cattle farming and fishing, because he cannot earn as much money as he wishes. According to him,

My father as well as my other family members belong to a traditional cattle farming family and over many years they have used Kadarwara tank and the surrounded forest area for grazing the herds of cattle. Before the 1980s, there were a very few forest conservation laws and regulations. But now it is not easy to use forest area for traditional forest utilization practices. Chena cultivation and hunting are totally banned [according to participatory and direct observation experience of the research, hunting and Chena cultivation are still in practice, even though they are against the law]. From the last few years, my father and other traditional farmers have to pay $18000.00 \mathrm{Rs}$ rental to the government to use Kdawara tank and use the forest for grazing our animals. So cattle farming in forest area is no more a 'profitable business' [SSI02- A2: A's $3^{\text {rd }}$ son, 37 years old married livestock farmer, 2016.10.15 (This statement was cross checked and was proved by SSI11, 13, 14,08 \& FGI 01, 04)].

Even if traditional forest utilization patterns are based on feudal norms and values, these norms and values are less important to the present-day farmers since they consider earning 'profit' is more important under the influence of superimposed capitalism (Kumara, 2016; Moore, 1990). A cannot change, since he represents feudal systems, yet A2 finds it is hard to fit in to the current social structure without being changed accordingly with the social change. (Gramsci, 2011). As A2 state:

To become a pig and poultry farmer is more profitable than being a cattle farmer. Yet, my father [A] does not like this idea since he strongly believes that this type of farming is sinful. But I have started pig and poultry 
farms in the forest area and I use Kadawara tank also for water needs. I do not care about business being meritorious or sinful according to religious views or morals. (SSI02- A2).

Concepts of $\sin$, merit and soul are norms of traditional (feudal) socioeconomic superstructure, yet when changes occur in the superstructure and cultural hegemony, such concepts are no longer in force (Salamini 2014). But the issue is that when forest utilization practices change from cattle faming to pig and poultry farming, its environmental impact change negatively. A2's herds of pigs are let loose into the forest to scavenge food from 8.30 in the morning to $6.00 \mathrm{p} . \mathrm{m}$. thus these pigs eat whatever they can eat on their way in the forest biosystems. Compared with the effects of cattle framing on ecosystem, this is more harmful to the diversity of wild animal species such as reptile and amphibian species.

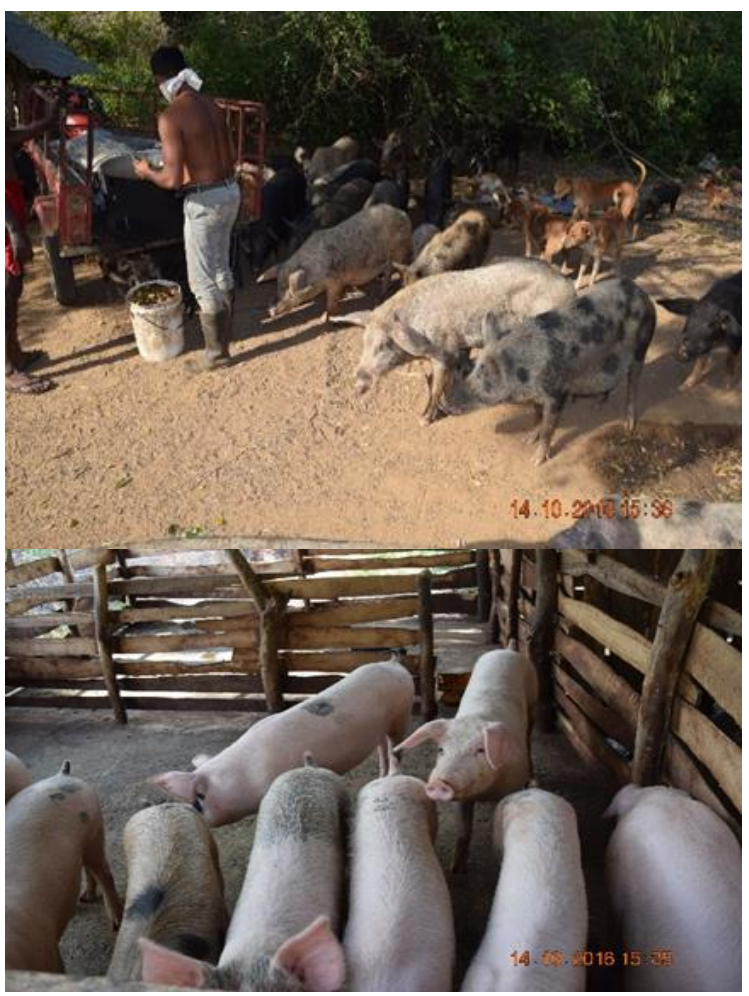

Figure 4. A2's pig farm within the forest close to Kadawara tank
On the other hand, illegal as well as destructive forest utilization practices such as Chena cultivation and hunting are still in practice in this site and the Forest Department and Department for Wildlife Conservation could not fully cease these activities.

Most importantly, such illegal forest utilization practices occurred in 'profit ordinated' superimposed capitalist social system is more harmful to the natural environment compared with forest utilization practices in a traditional feudal social system (Biel, 2015; Kumara, 2016).

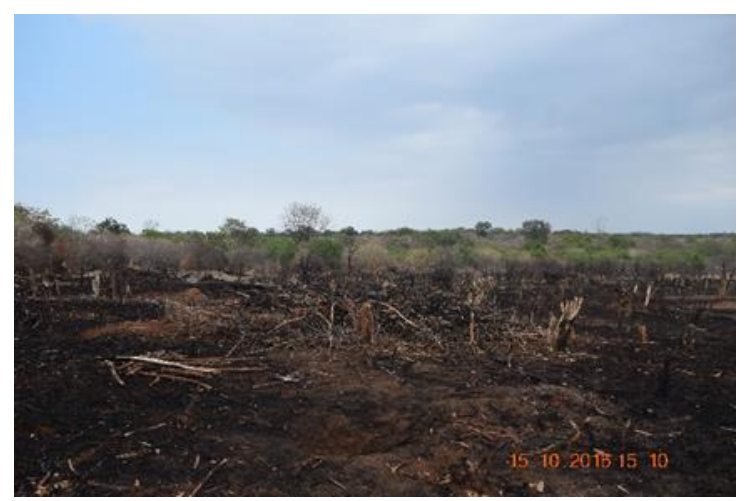

Figure 5. Setting fire to forestland for Chena cultivation

Third case study: B is a young married individual (about 40 years old). At present, he has temporarily immigrated to South Korea as a worker. The data mentioned below has been collected through participatory and direct observation experience of the research and information given by other villagers (his family and other relations).

B comes from a traditional farming family of the research site. But he was not happy to carry on like a traditional farmer as his forefathers did. Since he picked a different path. He had worked hard to learn Korean language and had applied for working visa in South Korea. When he got visa, he immigrated to $S$. Korea and started working as a labourer in a manufacturing company. Now he has almost spent 12 years there. 
Once in every four years he visits home. His family (wife and two children) lives in the village similar to any other ordinary rural villager. Children go to the state school in the village and his wife is a house person who attends to all the household matters. $\boldsymbol{B}$ earns a lot of money, but he does not invest his savings or start up any kind of income generating work. With all his money that he has earned during those 12 years in $S$. Korea, he has built a very big, luxurious house in the village with all the modern facilities. Amid in a rural, marginalized and isolated village, this house shows off owner's wealth and the achievements of his capitalist dreams. Even he has set several CCTV cameras inside and outside the house covering up most of the sections of his house and these cameras allow him to watch comfortably what is going on in his house while being in Korea (2016.10.14/15-field notes based on participatory and direct observation experience and information given by SSI01, 3, 5, 6, 9, 18, 14).

The research findings reveal that most of the village youth dream to migrate to Korea like $\mathbf{B}$ did and they are working hard to make their dream come true (going to Korean language classes; looking for support from regional politicians to obtain working visa to Korea etc.).

The bright side of this trend is that $\mathbf{B}$ and other young villagers have abandoned forest utilization practices, which leads to environmental conservation. It is observed that there is a trend of village youth migrating more to the outside world in future looking for ways to achieve their capitalist dreams (Shaw, 2010).

When capitalist dreams of $\mathbf{B}$ or the villagers who follow B's path are analysed, it can be identified how ridiculous are the norms/values in a capitalist superstructure in the world southern peripheral context of on which capitalism has been superimposed (De Silva, 2012; Gunasinghe, 1990; Jayawardena, 2000; Kumara, 2016; Ulyanovsky, 1981).

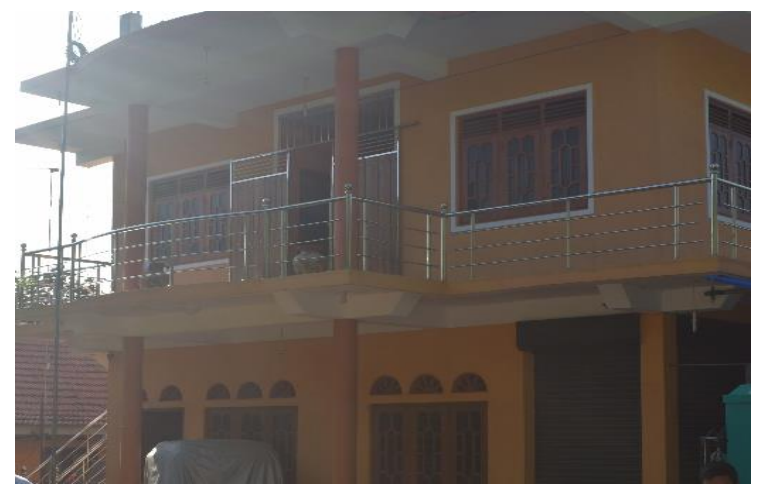

Figure 6. B's Luxurious house in the research site

Labourers in this context 'pretend' to be 'capitalists' and contribute to create an illusionary 'capitalist body' without a 'soul'. These people try to achieve western capitalist life by earning more and more money without understanding the fundamentals of western capitalism or its mechanism. In this kind of misleading and distorted system, it is hard to achieve development or sustainable development targets (Jayawardana, 2000; Kumara, 2016).

On the other hand, fantasies brought in through superimposed capitalism have led people in the southern peripheral context to live a lifeless life full of stress, jealousy and competition. For example; why does $\mathbf{B}$ wants to watch what is happening in his family from Korea? It can be considered as an act/ reflection of B's suppressed unconscious mind (Žižek, 1997). He is trying to achieve targets of his fantasies comparing himself with the 'big other' who is also a creation of his own mind. (Feldstein, Bruce \& Maire, 1995; Žižek, 1992). The most important observation here is that there are many others who are willing to follow the same way as $\mathbf{B}$ has taken and this trend can bring negative effects on social order, relationships, and systems.

\section{CONCLUSION}

Traditional forest utilization practices of the research site which are based on 'feudalcollectivist' values and norms, can be identified as comparatively sustainable systems. Yet with 
the increasing human population, socioeconomic structure change from 'feudal collectivist' to 'individualist- superimposed capitalist' structure. Accordingly, traditional forest utilization practices have also changed creating two major issues. First, traditional forest utilization practices have been converted into 'profit orientated businesses' and this has brought negative impacts on natural eco systems. Second, young people have migrated from the site to outside world looking for better ways of living. This has brought in positive effects on environmental conservation but negative effects on socio cultural settings since this leads to create a 'feudal-capitalist' social structure which does not result in better socioeconomic development. With capitalist fantasies being spread over feudal social structure, the structure has grown up to be a 'grotesque of capitalist superstructure'. It has led into a social anomie while negatively influencing the balance and harmony of the social order.

\section{REFERENCES}

ABRAMITZKY R. \& BRAGGION F. Malthusian and neo-Malthusian theories. In Mokur J. editor.The Oxford encyclopeida of economic history Oxford, UK: Oxford University Press. 2003; 423-427.

ADAMS WM. Green development: Environment and sustainability in a developing world 3rd ed. London: Routledge. 2009.

ALTIERI MA,\& MASERA O. Sustainable rural development in Latin America: Building from the bottom-up. Ecological Economics. 1993; 2: 93-121.

BANERJEE SB \& LINSTEAD S. Globalization, multiculturalism and other fictions: colonialism for the new millennium? Organization. 2001;4: 683-722.
BAKER S. The politics of sustainable development: Theory, policy and practice within the European Union. London: Routledge. 1997.

BALTAR F \& BRUNET I. Social research 2.0: Virtual snowball sampling method using Facebook. Internet Research. 2012; 1: 57-74.

BECKER H. S. Problems of inference and proof in participant observation. American Sociological Review. 1958; 6: 652-660.

BIEL R. The interplay between social and environmental degradation in the development of the international political economy. Journal of World-Systems Research. 2015; 1:109-147.

BLOOR M. \& BLOOR T. The practice of critical discourse analysis: An introduction. London: Routledge. 2013.

BOYATZIS RE. Transforming qualitative information: Thematic analysis and code development. London: Sage. 1998.

BREZIS ES. Can demographic transition only be explained by altruistic and neo-Malthusian models? The Journal of Socio-Economics. 2010; 2: 233-240.

BRYDON D. Postcolonialism now: Autonomy, cosmopolitanism, and diaspora. University of Toronto Quarterly. 2004; 2: 691-706.

BRYMAN A. Social research methods. 4th ed. Oxford: Oxford University Press. 2012.

CHAYANOV AV. On the theory of noncapitalist economic systems. The theory of peasant economy. 1966; 1:1-28.

CHENOWETHA J \& FEITELSONB E. NeoMalthusians and cornucopians put to the test: Global 2000 and the resourceful earth revisited. Futures. 2004; 1: 51-72. 
CLARK DA. The Elgar companion to development studies. Cheltenham: Edward Elgar Publishing. 2006.

COHEN $\mathrm{N}$ \& ARIELI T. Field research in conflict environments: Methodological challenges and snowball sampling. Journal of Peace Research. 2011; 4: 423-435.

COSTANTINOS BT. An overview of development theories. Addis Abeba: The Centre for Human Environment. 1998.

DAVIS JB. The turn in economics: Neoclassical dominance to mainstream pluralism? Journal of Institutional Economics. 2006; 2: 1-20.

DE SILVA SBD. The political economy of underdevelopment. London: Routledge. 2012.

DE SILVA SB. The political economy of underdevelopment. London: Routledge. 2012.

DESAI V. Community participation in development. In: V. Desai \& R. B. Potter, editors. The companion to development studies. London: Oxford University Press. 2002; 115119.

DESAI V \& POTTER RB. (Eds.). The companion to development studies. London: Arnold. 2002.

DEY, I. Qualitative data analysis: A userfriendly guide for social scientists. London: Routledge; 2003.

D'HAUTESERRE AM. Postcolonialism, colonialism, and tourism. In Lew, A A. Hall C M \& Williams A M. editors. A companion to tourism. London: Wiley-Blackwell. 2004; 235245.

DIRLIK A. Rethinking colonialism: Globalization, postcolonialism, and the nation. Interventions. 2002; 4:428-448.
DIRLIK A. The postcolonial aura: Third world criticism in the age of global capitalism. Critical Inquiry. 1994; 2: 328-356.

DUNHAM D \& JAYASURIYA S. Equity, growth and insurrection: Liberalization and the welfare debate in contemporary Sri Lanka. Oxford Development Studies. 2000; 28: 97-110.

DUNHAM D \& KELEGAMA S. Economic liberalization and structural reforms: the experience of Sri Lanka, 1977-93. ISS Working Paper Series/General Series. 1994; 163:1-37.

FELDSTEIN R, BRUCE F \& MAIRE J, (eds). Reading Seminar XI: Lacan's Four Fundamental Concepts of Psychoanalysis: The Paris Seminars in English. New York: SUNY Press. 1995.

FERNANDO P, JAYEWARDENE J, PRASAD T, HENDAVITHARANA W \& PASTORINI J. Current status of Asian elephants in Sri Lanka. Gajah. 2011; 35: 93-103.

FERRARO V. Dependency theory: An introduction. In Secondi G, editors. The development economics reader London: Routledge. 2008; 58-64.

FEWEL GR. A socialist model of economic development: The Polish and Bulgarian experiences. World Development. 1981; 9: 929950.

FISCHER F \& HAJER M. Living with nature: Environmental politics as cultural discourse. Oxford: Oxford University Press. 1999.

FORGACS D, NOWELL-SMITH G \& BOELHOWER W. Antonio Gramsci: Selections from cultural writings. London: Lawrence \& Wishart. 2012.

FRIEDMANN H \& WAYNE J. Dependency theory: A critique. Canadian Journal of Sociology. 2012; 2: 399-416. 
GUILLEMIN M \& GILLAM L. Ethics, reflexivity, and 'ethically important moments' in research. Qualitative Inquiry. 2004; 2: 261280.

GUNASINGHE N. Changing socio-economic relations in the Kandyan countryside. Colombo: Social Scientists' Association. 1990.

GRAMSCI A. Prison Notebooks, Volumes 1-3. New York: Columbia University press. 2011.

HALL CM \& TUCKER H. Tourism and postcolonialism: Contested discourses, identities and representations. London: Routledge. 2004.

HAWKEN P, LOVINS AB \& LOVINS LH. Natural capitalism: The next industrial revolution, London: Routledge. 2013.

HOLLINSHEAD K. Tourism and new sense: World making and the enunciative value of tourism. In Hall CM \& Tucker H, editors. Tourism and postcolonialism: Contested discourses, identities and representations London, UK: Routledge. 2004. P.25-42.

IVANOVA M. Moving forward by looking back: Learning from UNEP's history. New York, NY: Center for UN Reform Education. 2007.

JAYAWARDENA K. Nobodies to somebodies: the rise of the colonial bourgeoisie in Sri Lanka. London: Zed Books. 2000.

KOBBEKADUWA H. Farming systems of Kirindi Oya irrigation and settlement project. 1998. http://dl.nsf.ac.lk/ohs/harti/22225.pdf. Accessed 08 February 2017.

KUMARA HIGC. Forest Utilization by Local Communities in Sinharaja Rain Forest. Saarbrücken: LAP LAMBERT Academic Publishing. 2014.
KUMARA HIGC. Challenges to Implementing Community Based Ecotourism (CBET) as a Bottom up Development Approach in the Sinharaja Rain Forest (Sri Lanka). Hamilton: University of Waikato. 2016. http://researchcommons.waikato.ac.nz/handle/1 0289/9894. Accessed 10 February 2017.

MAY T. Social research: Issues, methods, and process (2nd ed.). Philadelphia, PA: Open University Press. 1997.

MENGE BA. Community regulation: under what conditions are bottom-up factors important on rocky shores? Ecology. 1992; 3:755-765.

MOORE M. Economic liberalization versus political pluralism in Sri Lanka? Modern Asian Studies. 1990; 24: 341-383.

PARNWELL MJG. Agropolitan and bottom up development. In Desai V \& Potter RB, editors. The companion to development studies. London: Oxford University Press. 2002; 112116.

PARROTTA JA, TURNBULL JW \& JONES N. Catalyzing native forest regeneration on degraded tropical lands. Forest Ecology and Management. 1997; 1:1-7.

POLITONOMIST. A history of famous economists. 2009. http://www.politonomist.com/a-history-offamous-economists-00305/2/. Accessed 12 February 2017.

POTTER RB. Theories, strategies and ideologies of development. In V. Desai \& R. B. Potter, editors. The companion to development studies. London: Oxford University Press. 2002; 61-65.

REDCLIFT MR. Sustainable development. In Desai V \& Potter RB, editors. The companion to development studies London: Oxford University Press. 2002; 275-278. 
REED MS. Stakeholder participation for environmental management: A literature review. Biological Conservation. 2008; 10: 2417-2431.

ROBERT WOOD JONSON FOUNDATION. Qualitative research guidelines project. 2012. http://www.qualres.org/HomeRefl-3703.html. Accessed 16 February 1998.

SALAMINI L. The Sociology of Political Praxis (RLE: Gramsci): An Introduction to Gramsci's Theory. London: Routledge. 2014.

SCHUMPETER JA. Capitalism, socialism and democracy. London: Routledge. 2013.

SEKHRI S. Dependency approach: Chances of survival in the 21st century. African Journal of Political Science and International Relations. 2009; 3: 242-252.

SHAW J. From Kuwait to Korea: the diversification of Sri Lankan labour migration. Journal of the Asia Pacific Economy. 2010; 1:59-70.

SMITH A. The wealth of nations. New York: Seedbox Press. 2015 -1776.

STOKKE K. Authoritarianism in the age of market liberalism in Sri Lanka. Antipode. 1997; 29: 437-455.

TIESSEN JH. Individualism, collectivism, and entrepreneurship: A framework for international comparative research. Journal of Business Venturing. 1997; 5: 367-384.

THOMAS LJ. Neoclassical development theory and the prebisch doctrine: A synthesis. American Economist. 2012; 38:75-81.

TRIANDIS HC, CHEN XP \& CHAN DKS. Scenarios for the measurement of collectivism and individualism. Journal of cross-cultural psychology. 1998; 2:275-289.
TURNER BS. Individualism, capitalism and the dominant culture: A note on the debate. The Australian and New Zealand Journal of Sociology. 1988; 24: 47-64.

ULYANOVSKY R. Agrarian India between the World Wars: A Study of Colonial-Feudal Capitalism. Moscow: Progress publisher. 1981.

VERNENGO M. Dependency theory: University of Utah. 2012. http://www.econ.utah.edu/ vernengo/papers/pri nceton.pdf . Accessed 15 February 2017.

WALKER S, READ S \& PRIEST H. Use of reflexivity in a mixed-methods study. Nurse Researcher. 2013; 3:38-43.

WEERASINGHE KDN, JAYASINGHE A \& ABEYSINGHE AMH. Securing the food supply and food security of the Ruhuna Basin. Imbulana, KAU. 2002. http://publications.iwmi.org/pdf/H031115.pdf. Accessed 08 February 2017.

ZIAI A. Postcolonialism and development: Disparate tales reconsidered development and change. 2011; 5:1297-1306.

ZIZEK S. Nature and its discontents. SubStance, 2008; 3: 37-72.

ŽIŽEK S. The plague of fantasies. Tennessee: Verso. 1997.

ŽIŽEK S. Looking awry: An introduction to Jacques Lacan through popular culture. Massachusetts: MIT press. 1992. 